ISSN 0258-7122 (Print), 2408-8293 (Online)

Bangladesh J. Agril. Res. 43(1): 159-168, March 2018

\title{
ADOPTION OF LENTIL VARIETIES IN BANGLADESH: AN EXPERT ELICITATION APPROACH
}

\author{
M. A. RASHID ${ }^{1}$, T. M. B. HoSSAIN ${ }^{2}$, M. E. HoQUE ${ }^{3}$ \\ M. M. RAHMAN ${ }^{4}$ AND K. S. RAHMAN ${ }^{5}$
}

\begin{abstract}
The study was undertaken to find out variety wise adoption rate of lentil in Bangladesh through expert elicitation procedure. Many varieties have been developed by BARI and BINA but in details of varietal information and adoption information database was not developed which is very important and valuable for the scientist and policy planner. From all over the Bangladesh, 12 experts was invited to share their valuable knowledge and experience on lentil cultivation and adoption in the country. The average age of the experts were 51 yrs and average experience on lentil adoption was 21 yrs. The lentil expert informed that 16 major varieties are adopted by the farmers in the recent year (2013-14). Among those varieties, BARI Masur-6 covered highest cultivated area $(54,642$ ha) which shared $30.04 \%$ of total lentil cultivated area. BARI Masur-4, BARI Masur-3 and BARI Masur-5 ranked $2^{\text {nd }}, 3^{\text {rd }}$ and $4^{\text {th }}$ position according to the share of cultivated area covered. The seed production information showed that BADC the only lentil seed producer supplied $2151 \mathrm{mt}$ of lentil seed in the year 2009-2013.The adoption of variety BARI Masur-6 increased due to its high yield attribute. The another variety BARI Masur-4 and BARI Masur-3 adoption increased due to its high yield, resistant to rust disease attributes which showed increasing adoption path among the expert. Satisfying higher demand for lentil consumption and ensuring food security through providing alternative to winter crops are the major concerning issue of the policy planner and the scientist. To ensure nutrition security in the country, it is very important to encourage and support the farmers to grow more lentil through providing improved cultivation technology to the farmers.
\end{abstract}

Keywords: economics, expert elicitation, varietal adoption

\section{Introduction}

Lentil (Lens culinaris M.) is among the important pulse crops contributing to food and nutritional security of people in Asia and Africa. Its seed contain high levels of protein, macronutrients, micronutrients and vitamins that provide nutritional security to poor consumers who cannot afford animal products due to high prices. Additionally, lentil straw is valuable feed for animals. Growing lentils in rotations provides sustainable cereal-based cropping systems.

${ }^{1}$ Principal Scientific Officer, ${ }^{2}$ Senior Scientific Officer, Agricultural Economics Division, Bangladesh Agricultural Research Institute (BARI), Gazipur, ${ }^{3}$ Senior Scientific Officer, Hill Tract Agricultural Research Station, Ramgarh, Khagrachari, ${ }^{4}$ Scientific Officer, Pulse Research Sub-Center, BARI, Gazipur, ${ }^{5}$ Scientific Officer, ASICT Division, BARI, Gazipur, Bangladesh. 
Bangladesh rank in $3^{\text {rd }}$ among the lentil growing countries of Asia Pacific region. Lentil is the second most important pulse crop in area and production, but stands first in the consumer's preference in this country.

It is grown on about 153912 ha, producing 127159 tonnes of grain, with average yield of $850 \mathrm{~kg} \mathrm{ha}^{-1}$ (Table 1.1) and contributes about $28 \%$ to the total pulses production. Lentil is cultivated during winter (rabi of post rainy season; NovMar). Cultivation of lentil is mainly concentrated within the Gangetic floodplains in the northern and southern districts.

Table 1.1. Area, production and yield of lentil in Bangladesh

\begin{tabular}{l|cccc}
\hline Year & Area (ha) & Production $(\mathrm{mt})$ & Yield $(\mathrm{t} / \mathrm{ha})$ \\
\hline $1990-91$ & 210172 & 157280 & 0.748 \\
$1991-92$ & 209004 & 152820 & 0.731 \\
$1992-93$ & 207532 & 163425 & 0.787 \\
$1993-94$ & 207642 & 167615 & 0.807 \\
$1994-95$ & 207356 & 167945 & 0.810 \\
$1995-96$ & 205868 & 169945 & 0.826 \\
$1996-97$ & 206439 & 170505 & 0.826 \\
$1997-98$ & 205858 & 162775 & 0.791 \\
$1998-99$ & 205577 & 165315 & 0.804 \\
$1999-00$ & 166781 & 127750 & 0.766 \\
$2000-01$ & 164567 & 125905 & 0.765 \\
$2001-02$ & 157229 & 115205 & 0.733 \\
$2002-03$ & 154123 & 115590 & 0.750 \\
$2003-04$ & 154810 & 122225 & 0.790 \\
$2004-05$ & 153899 & 121065 & 0.787 \\
$2005-06$ & 134694 & 115370 & 0.857 \\
$2006-07$ & 137613 & 116810 & 0.849 \\
$2007-08$ & 72613 & 71535 & 0.985 \\
$2008-09$ & 70983 & 60537 & 0.853 \\
$2009-10$ & 77321 & 71100 & 0.920 \\
$2010-11$ & 83006 & 80442 & 0.969 \\
$2011-12$ & 86245 & 80125 & 0.929 \\
$2012-13$ & 90002 & 93098 & 1.034 \\
$2013-14$ & 124549 & 157422 & 1.263 \\
\hline
\end{tabular}

Source: BBS (1992), BBS (1997), BBS (2004), BBS (2008), BBS (2012), BBS (2014). 
Research on lentil was initiated during the early 1950s.Where efforts were confined to the collection and evaluation of local germplasm. A few lines were tested over locations during the early 1960s, but the research virtually stopped, as the germplasm was not properly maintained. To halt steady decline and to attain self-sufficiency in pulses production, an intensive research effort was launched at the Bangladesh Agricultural Research Institute in 1979 under a research grant project of the International Development Research Centre (IDRC), Canada. Eventually the Pulses Improvement Program transformed into a Pulses Research Centre (PRC), in mid-eighties with its 4-5 testing stations at major pulsesgrowing zones of the country.

With the detailed adoption information, the concern authority and agencies can formulate appropriate policy for the development of lentil crop across the country. Again, potential adoption of the improved varieties would generate employment and additional income for the rural poor and save foreign exchange through producing more of this crop utilizing fallow and under used lands in the country. Therefore, nationally representative and up-to-date data and information on the adoption of lentil cultivation are lacking in Bangladesh. This information could be useful for both government and donor agencies in investing more on lentil improvement programs in Bangladesh.

\subsection{Objectives for the study}

i) To document and process on varietal release at the national level

ii) To find out variety wise adoption rate of lentil in Bangladesh and

iii) To suggest policy implications from the above.

\section{Methodology}

\subsection{Data and data sources}

The main approach is to assemble the relevant data for the most recent years from multiple sources such as national data sources (BBS, DAE), Annual Report of pulse research center of BARI, BARI \& BINA annual report, Books of BARI developed crop varieties, consultation with related scientists and expert elicitation (EE) workshop.

\subsection{Details of experts}

A panel of experts knowledgeable about the adoption of lentil cultivars in the zones (ecosystem, season or administrative zone) was formed. Typically, a panel consisted of 12 experts including scientists (breeders, agronomists, and agricultural economists), extension workers, seed producers \& traders, development worker and farmers about lentil production systems in the locality 
(Table 2.1). Among the experts, 5 members were from NARS and 7 members were from non-NARS at the EE workshop in Bangladesh.

Table 2.1. Distribution of expert according to discipline

\begin{tabular}{l|c|c|c}
\hline Discipline of experts & $\begin{array}{c}\text { No. of experts by } \\
\text { discipline }\end{array}$ & $\begin{array}{c}\text { No of experts from } \\
\text { NARS }\end{array}$ & $\begin{array}{c}\text { No of experts from } \\
\text { non-NARS }\end{array}$ \\
\hline Scientist & 6 & 5 & 1 \\
Extension & 3 & - & 3 \\
Development worker & 1 & - & 1 \\
Farmers & 1 & - & 1 \\
Seed production expert & 1 & - & 1 \\
Total & 12 & 5 & 7 \\
\hline
\end{tabular}

Source: Expert Elicitation workshop-2015.

Lentil is grown in most of the areas of Bangladesh. As per the statistics of DAE, the total area under lentil cultivation is 0.18 million hectare with the production of 2.16 million tons during 2013-14. The adoption study of lentil variety has been taken-up top four zones of Rajshahi, Jessore, Barisal zone of Bangladesh because they were the top producer's zones of lentil occupying an area $92.36 \%$ and production of about 94\% during 2013-14 (Table 2.2).

Table 2.2. Zone wise gross cropped areas and production of lentil during 2013-14

\begin{tabular}{l|c|c|c|c}
\hline \multirow{2}{*}{ Crop Zone } & \multicolumn{4}{|c}{ Lentil } \\
\cline { 2 - 5 } & $\begin{array}{c}\text { Gross cropped area } \\
\text { (ha) }\end{array}$ & Share (\%) & Production (MT) & Yield (t/ha) \\
\hline Rajshahi Zones & 59939 & 32.95 & 78928 & 1.32 \\
Jessore Zones & 65442 & 35.97 & 86763 & 1.33 \\
Barisal Zones & 42631 & 23.44 & 50538 & 1.19 \\
Others & 13893 & 7.64 & 15974 & 1.15 \\
Total & 181905 & 100.00 & 232203 & 1.28
\end{tabular}

Source: DAE, 2014.

\section{Results and Discussion}

\subsection{More details about experts}

Age of experts plays an important role to share knowledge regarding the varietal adoption in EE workshop. The average age of the expert was $50.75 \mathrm{yrs}$ and the range of their age was from 28 to 69 yrs (Table 3.1). The average year of experience on lentil was 19.83 yrs and the experience of expert range from 5 to 31 yrs. Expert who were invited in the workshop had $21.25 \mathrm{yrs}$ of average 
working experience in the affiliated organization. The working experience (yrs) of the experts in the organization ranged from 9 to 31 yrs.

Table 3.1. Qualification of expert's characteristics

\begin{tabular}{lc|c|c}
\hline \multicolumn{1}{c|}{ Expert characteristics } & Mean & Min & Max \\
\hline Age (years) & 50.75 & 28 & 69 \\
Years of experience on crop & 19.83 & 5 & 31 \\
Years of experience in present institute & 21.25 & 9 & 31 \\
\hline
\end{tabular}

Source: Expert Elicitation workshop-2015.

\subsection{Trends in varietal release}

BARI began a program in the mid 1990 to develop its own lentil variety in collaboration with international partners, particularly ICARDA, and it released its first lentil (BARI Masur-1 and 2) in 1991 and 1993 respectively. Two further lentil BARI Masur-3\&4 (released in 1996) and BARI Masur-5, released in 2006. BARI has released two other lentil variety BARI Masur-6 (released in 2006), BARI Masur-7 (released in 2011) (Table 3.2).

Table 3.2. Number of variety released in different period

\begin{tabular}{l|c|c}
\hline \multicolumn{1}{c|}{ Period } & Total varieties & No. of modern varieties \\
\hline $1991-1995$ & 2 & 2 \\
$1996-2000$ & 2 & 2 \\
$2001-2005$ & 3 & 3 \\
$2006-10$ & 3 & 3 \\
2010 till now & 6 & 6 \\
Total & 16 & 16 \\
\hline
\end{tabular}

Source: BARI, 2010-2012.

The variety cultivated in Bangladesh, all of them are officially developed and released varieties. Variety developed are $100 \%$ modern variety. The variety that is developed locally are released by government authority. The developed varieties have linkage with NARS and international organization like ICARDA of CGIAR. Among the modern varieties (16) of lentil the top most contributor was NARS (62.5\%) followed by CGIAR (37.5\%) (Table 3.3).

Table 3.3. Share of contribution and linkage of different organization in varietal Development

\begin{tabular}{c|c|c|c|c}
\hline Crop & $\begin{array}{c}\text { Total } \\
\text { number of } \\
\text { varieties }\end{array}$ & $\begin{array}{c}\text { Number of } \\
\text { varieties linked } \\
\text { with CGIAR }\end{array}$ & $\begin{array}{c}\text { Number of } \\
\text { varieties linked } \\
\text { with NARS }\end{array}$ & $\begin{array}{c}\text { Number of varieties } \\
\text { linked with Private Sector } \\
\text { companies/ institutions }\end{array}$ \\
\hline Lentil & 16 & $6(37.5 \%)$ & $10(62.5 \%)$ & 0 \\
\hline
\end{tabular}

Source: Expert Elicitation workshop-2015. 
Among the modern varieties (16), NARS was the key role player to develop lentil varieties during period 1991-2014 followed by NARS (10) and CGIAR (6) in Bangladesh. Highest number of lentil variety (6) developed and released in the country during the period 2010 and onward. In that period NARS developed 4 varieties and rest of the varieties are developed by the NARS with the linkage of CGIAR (Table 3.4).

Table 3.4. Number of varieties linked with CGIAR, NARS

\begin{tabular}{l|c|c|c}
\hline \multicolumn{1}{c|}{ Period } & Total MV's & $\begin{array}{c}\text { Number of varieties } \\
\text { linked with CGIAR }\end{array}$ & $\begin{array}{c}\text { Number of varieties } \\
\text { linked with NARS }\end{array}$ \\
\hline $1991-1995$ & 2 & 1 & 1 \\
$1996-2000$ & 2 & 1 & 1 \\
$2001-2005$ & 3 & & 3 \\
$2006-10$ & 3 & 2 & 1 \\
2010 till now & 6 & 2 & 4 \\
Total & 16 & 6 & 10 \\
\hline
\end{tabular}

Source: BARI, 2010-2012.

Table 3.5. Percentage of adoption areas mentioned by expert

\begin{tabular}{l|c|c}
\hline $\begin{array}{c}\text { List top Modern Variety (MV) } \\
\text { as identified in EE }\end{array}$ & $\begin{array}{c}\text { Total country/ domain } \\
\text { cropped/ net sown area (ha) }\end{array}$ & $\begin{array}{c}\text { \% Area adopted under the } \\
\text { variety (ha) by EE }\end{array}$ \\
\hline BARI Masur-1 & 3094.74 & 1.70 \\
BARI Masur-2 & 3409.63 & 1.87 \\
BARI Masur-3 & 23834.82 & 13.10 \\
BARI Masur-4 & 42592.87 & 23.41 \\
BARI Masur-5 & 13454.6 & 7.40 \\
BARI Masur-6 & 54642.25 & 30.04 \\
BARI Masur-7 & 8711.97 & 4.79 \\
Binamasur-1 & 1893.27 & 1.04 \\
Binamasur-2 & 1262.6 & 0.69 \\
Binamasur-3 & 1322.81 & 0.73 \\
Binamasur-4 & 0 & 0.00 \\
Binamasur-5 & 3530.97 & 1.94 \\
Binamasur-6 & 0 & 0.00 \\
Binamasur-7 & 0 & 0.00 \\
Binamasur-8 & 0 & 0.00 \\
Binamasur-9 & 0 & 0.00 \\
\hline
\end{tabular}

Source: Expert elicitation workshop, 2015. 


\subsection{Trends in varietal adoption}

An attempt was made to assess the level of adoption in terms of percent of farmers adopted lentil variety at farm level. The level of adoption of lentil variety was mostly depended on the dissemination process used by BARI, BINA in association with the DAE. The finding of the EE workshop revealed that the farmers adopted lentil varieties such as BARI Masur-6, BARI Masur-4 and BARI Masur-3. BARI Masur-6 was highly adopted variety (30.04\%) followed by BARI Masur-4 (23.41\%), BARI Masur-3 (13.1\%), BARI Masur-5 (7.4\%), BARI Masur-7 (4.79\%), Binamasur-5 (1.94\%), BARI Masur-2 (1.87\%), and BARI Masur-1 (1.7\%) (Table-3.5). Others varieties such as Binamasur-1, Binamasur-2 and Binamasur-3 etc. occupied rest of the total lentil areas in Bangladesh (Table3.5).

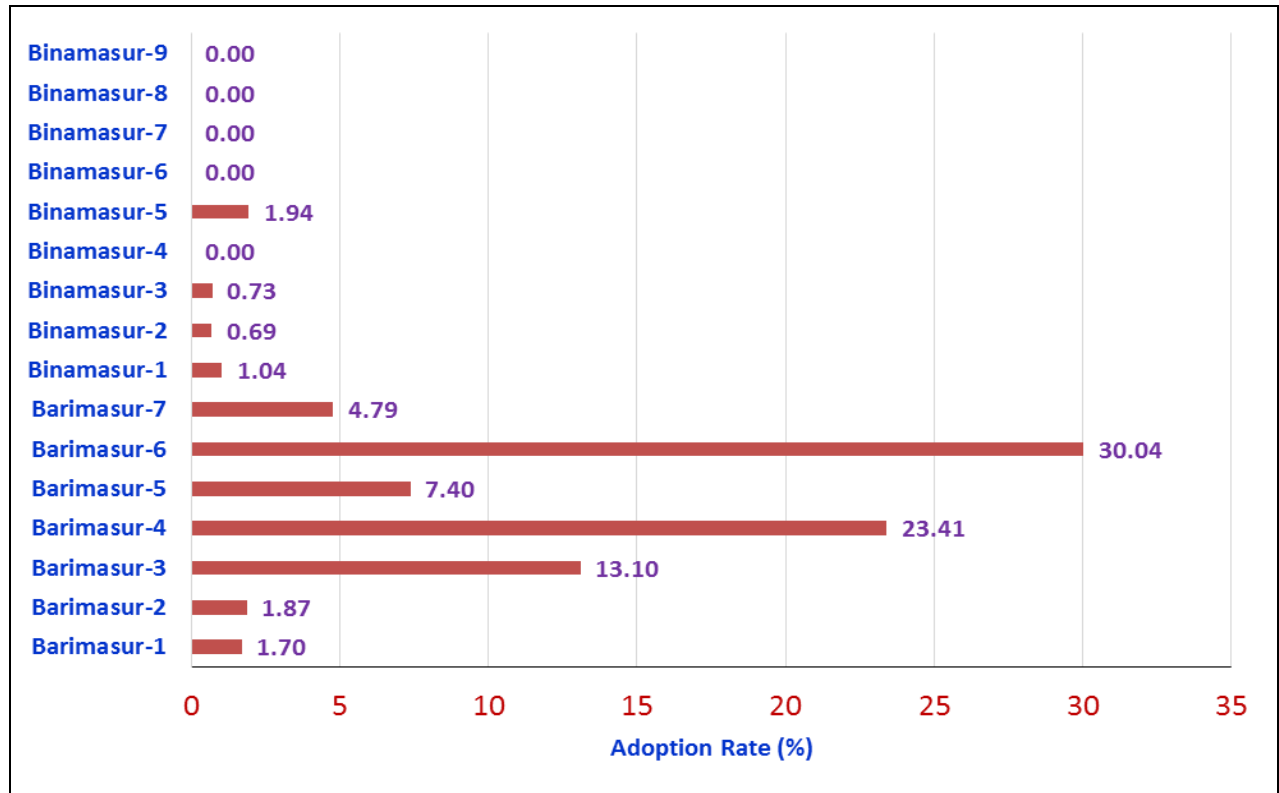

Fig. 1. Varietal Adoption of Lentil in Bangladesh

\subsection{Adoption statistics seen in literature}

There is no detail lentil varietal adoption study in Bangladesh. Matin et al. (2014) conducted a study regarding varietal adoption of lentil in some selected areas and found that BARI Masur-6 is the dominant variety followed by BARI Masur-3, BARI Masur-4, and BARI Masur-5 in the selected areas which covered 36.11\%, $29.63 \%, 20.37 \%$ and $5.37 \%$ respectively of total lentil areas (Table-3.6). Some results supported and some results did not support with the percentage of adoption level mentioned by the expert. The difference might be due to variation in study location selection, source of information. As because there is no variety 
wise adoption level information of lentil at national level, so variety wise cultivation area coverage information is hard to collect. In this condition, researcher try to collect varietal adoption information from department of agricultural extension, local businessman of very specific locations.

Table 3.6. Adoption area and their difference with other sources

\begin{tabular}{l|c|c|c}
\hline $\begin{array}{c}\text { List top MV variety } \\
\text { as identified in EE }\end{array}$ & $\begin{array}{c}\text { \% Area adopted under } \\
\text { the variety (ha) by EE }\end{array}$ & $\begin{array}{c}\text { \% Area adopted under } \\
\text { the variety (ha) as seen } \\
\text { in literature/ national } \\
\text { survey/ other source }\end{array}$ & $\begin{array}{c}\text { \% difference } \\
\text { between the two }\end{array}$ \\
\hline BARI Masur-1 & 1.70 & - & - \\
BARI Masur-2 & 1.87 & - & - \\
BARI Masur-3 & 13.10 & 29.63 & -16.53 \\
BARI Masur-4 & 23.41 & 20.37 & 3.04 \\
BARI Masur-5 & 7.40 & 5.37 & 2.03 \\
BARI Masur-6 & 30.04 & 36.11 & -6.07 \\
BARI Masur-7 & 4.79 & 1.30 & 3.49 \\
Binamasur-1 & 1.04 & - & - \\
Binamasur-2 & 0.69 & - & - \\
Binamasur-3 & 0.73 & - & - \\
Binamasur-4 & 0.00 & - & - \\
Binamasur-5 & 1.94 & - & - \\
Binamasur-6 & 0.00 & - & - \\
Binamasur-7 & 0.00 & - & - \\
Binamasur-8 & 0.00 & - & - \\
Binamasur-9 & 0.00 & - & - \\
\hline Sol & & - & - \\
\hline
\end{tabular}

Source: Expert elicitation workshop, 2015 \& Matin et al. (2014).

\subsection{Variety wise quantities of foundation seed}

Seed production information is also not widely available from the sources. Seed production information for private seed producer is hard to collect compare to public seed producer organization. Seed production information of breeder seed was available from BADC only. In the year 2009-2013, the foundation seed production of BARI Masur-3 was highest in amount $(897 \mathrm{mt})$ followed by BARI Masur-6 (640mt) and BARI Masur-5 (345 mt) (Table-3.7). The change in seed production over the period (2009-2013) showed that BARI Masur-3 increased sharply but BARI Masur-4 gradually decreased. 
Table 3.7. Average seed production by the BADC seed producer over the period 2009-2013

\begin{tabular}{l|c}
\hline \multicolumn{1}{c|}{ Variety name } & Produced foundation seed (2009-2013) Ton \\
\hline BARI Masur-1 & - \\
BARI Masur-2 & - \\
BARI Masur-3 & 897 \\
BARI Masur-4 & 256 \\
BARI Masur-5 & 345 \\
BARI Masur-6 & 640 \\
BARI Masur-7 & 13 \\
Binamasur-1 & 0 \\
Binamasur-2 & 31.68 \\
Binamasur-3 & 9.3 \\
Binamasur-4 & 4.46 \\
Binamasur-5 & 9 \\
Binamasur-6 & 9 \\
\hline
\end{tabular}

Source: BADC, 2015

\subsection{Varieties attributes}

Experts asked in the EE workshop that the farmers to give preference for cultivation existing varieties due to high yielder, disease resistant. The adoption of variety BARI Masur- 6 increased due to its high yield attribute. The another variety BARI Masur-4 and BARI Masur-3 adoption increased due to its high yield, resistant to rust disease attributes.

In case of earlier popular varieties were gone out from the farmer's preferences due to best varieties available to the farmers, tolerance to disease, easy seed production and storage, rust disease resistance and change in consumption preferences.

\section{Conclusion and Recommendation}

Very valuable information about lentil was collected through the elicitation of 12 experts who had expertise of different discipline of pulse sector through involving in lentil research and extension at different corners of the country. On an average, the expert's age was 51 years, and had 21 years of experience on lentil research and extension.

The adoption rate information provided by experts revealed that 12 different varieties were cultivated on highest percentage of cultivation area. Among those cultivated varieties, finding of the EE workshop revealed that the farmers 
adopted lentil varieties such as BARI Masur-6, BARI Masur-4 and BARI Masur3 etc. BARI Masur-6 was highly adopted variety (30.04\%) followed by BARI Masur-4 (23.41\%), BARI Masur-3 (13.1\%), BARI Masur-5 (7.4\%), BARI Masur-7 (4.79\%), Binamasur-5 (1.94\%), BARI Masur-2 (1.87\%), and BARI Masur-1 (1.7\%). Others varieties such as Binamasur-1, Binamasur-2 and Binamasur-3 etc. occupied rest of the total lentil areas in Bangladesh. A difference was found between the percentage of adoption area mentioned by the experts and percentage found in secondary source. The difference in adoption percentage might be due to different study year and also difference in study area location. Seed production information is not publicly available. In spite of that, the breeder seed information from BADC showed that BARI Masur-3 increased sharply but BARI Masur-4 gradually decreased.

The adoption of variety BARI Masur-6 increased due to its high yielder attribute. The another variety BARI Masur-4 and BARI Masur-3 adoption increased due to its high yield, resistant to rust disease attributes.

Variety developed by NARS with the support of ICARDA has a small share in adoption status. This indicated that there is a very wide scope to give more emphasis on varietal improvement of lentil by NARS. To ensure nutrition security in the country, it is very important to encourage and support the farmers to grow more lentil through providing improved cultivation technology to the farmers.

\section{References}

Afzal, M.A., M.A. Bakr, A. Hamid, M.M. Haque and M.S. Akter. 2003. Lentil in Bangladesh, Lentil Black gram and Mungbean Development Pilot Project

BARI. 2010, 2011, 2012. Bangladesh Agricultural Research Institute Annual Research Report

BINA. 2012. BINA Developed Higher Agricultural Technology Details, Bangladesh Nuclear Agricultural Research Institute.

DAE. 2014. Yearly database information, Monitoring unit, Department of Agricultural Extension, Ministry of Agriculture.

Matin, et.al. 2014. Assessment of Socio-Economic Impacts on Pulses Research and Development in Bangladesh

Rashid, M.H. Rajib Podder, M. Sahenuzzaman, M. Omor Ali, M. Asraf Hossain, M. Jalal Uddin, and AHM Mahfuzul Haque. 2013. SPGR-CGP Project, Pulse Research Centre, Ishurdi, Pabna and Regional Agricultural Research Centre, Barisal. 